\title{
Field Survey on Extent of Adoption of Improved Dairy Husbandry Techniques in Erode District of Tamil Nadu, India
}

\author{
T. Geetha* , P. Tensingh Gnanaraj, U. Lakshmikantan, \\ R. Mathivanan and S. Manokaran ${ }^{5}$
}

Veterinary University Training and Research Centre, Tamil Nadu Veterinary and Animal Sciences University, Veterinary Hospital campus, Kamarajarsalai, Tirpur-641 604, Tamil Nadu, India

*Corresponding author

\section{Ke y w o r ds \\ Adoption, Dairy husbandry technique, Erode District \\ Article Info \\ Accepted: \\ 15 March 2020 \\ Available Online: \\ 10 April 2020}

\section{A B S T R A C T}

The present study was carried out in Erode district of Tamil Nadu to find out the extent of adoption of improved dairy husbandry techniques. A random sample of 300 dairy animal owners were selected and extent of adoption of improved dairy husbandry techniques in six major aspects of housing, feeding, breeding, health care, milking and calf rearing management was studied. Proper orientation of animal shed and housing in separate located place were more adopted in housing techniques. Provide clean and fresh drinking water, feeding balance concentrate mixture on the basis of milk production was more adopted in feeding management. Keeping watch on oestrus cycle and heat symptoms, service/insemination after 12-16 hours since onset of heat and artificial insemination of animals were more adopted by the dairy animal owners. Timely and regularly vaccination and observing animals daily for signs of sickness were more adopted. Hygienic milking and calf rearing techniques were more adopted by the dairy animal owners.

\section{Introduction}

Tamil Nadu is an important state in milk production and marketing in India on cooperative dairy system. Production potential of livestock depends mostly on the management practices under which they are reared and these practices vary significantly across various agro ecological regions due to many factors. Understanding of livestock management practices followed by farmers in a region is necessary to identify the strengths and weaknesses of the rearing systems and to formulate suitable intervention policies (Gupta et al., 2008). India has emerged as leading milk producer country in the world, 
however productivity per milking animal is very low i.e. wet average $\mathrm{kg}$ /day in indigenous cows, crossbred cows and buffalo as $1.98,6.75$ and 4.50 respectively (Hegde et $a l ., 2006)$. This low production in India is mainly due to lack of low level of knowledge and adoption of improved dairy husbandry practices by dairy farmers. The latest scientific adoption of dairy farming is based on the main pillars of innovative balanced feeding, breeding, proper management and health control, which are the major elements to create ideal and expected conditions in animal husbandry. Various management Practices are important for the health and production of dairy animals. The present study was therefore undertaken with the objective of extent of adoption of improved dairy husbandry techniques in Erode district of Tamil Nadu.

\section{Materials and Methods}

A field survey was conducted in Erode district of Tamil Nadu during December 2018 to October 2019. In Erode district five talukas were randomly selected. From each selected taluka 5 villages having functional primary milk producer's co-operative societies were selected at random. Twelve dairy animal owners from each village were randomly selected with the help of village dairy cooperatives which constituted total of 300 respondents. The selected dairy farmers were interviewed with the help of pre-designed and pre-tested questionnaire.

A simple adoption scale was used in the present study (Sharma et al., 1987). The scale contained sixty techniques, ten techniques from each of the area of housing, feeding, breeding, health care, milking and calf rearing management. Against each of the technique, there were three columns representing continued adoption, occasionally adopted and not adopted with weightage of 2, 1 and 0 respectively. The recorded responses were counted and mean score were calculated.

\section{Results and Discussion}

\section{Adoption of housing management techniques}

Data in Table 1 indicated that out of ten techniques included in adoption of housing management, housing in separate located place got the highest mean adoption score and occupied first rank. The second and third positions were occupied by proper orientation of animal shed and providing proper floor space, respectively. Proper height and ventilation, provision of pucca paved floor in the shed, keeping animals in the shed at night and outside during day time in winter season and vice-a-versa in summer, providing pucca manger, proper drainage and slope of floor, providing bedding material on the floor during winter and loose housing with seasonal modification were awarded $4^{\text {th }}, 5^{\text {th }}$ $, 6^{\text {th }}, 7^{\text {th }}, 8^{\text {th }}, 9^{\text {th }}$ and $10^{\text {th }}$ respectively. These present findings are in accordance with the findings of (Chowdhry et al., 2006; Gupta et $a l ., 2008$ ) who observed that majority (76 to $86 \%$ ) of the respondents had separate animal sheds. Further, the majority (55 to $60 \%$ ) of the houses of animals were in east-west direction reported by Kumar et al., (2011).

\section{Adoption of feeding management techniques}

Adoption of feeding management techniques presented in Table 2 revealed that provide clean and fresh drinking water got the highest mean score and occupied first rank. The second and third positions were occupied by feeding balance concentrate mixture on the basis of milk production and feeding extra ration to advance pregnant animals. Cultivation of green fodders, feeding mineral mixture, feeding green fodders to animal 
round the year, chaffing of dry fodders before feeding, feeding of common salt occupied the rank of $4^{\text {th }}, 5^{\text {th }}, 6^{\text {th }}, 7^{\text {th }}$ and $8^{\text {th }}$, respectively. Urea treatment for improving the poor quality paddy straw and preservation of surplus green fodders as hay and Silage jointly obtained last rank as not a single respondent has adopted this technique. The present results of feeding balance concentrates mixture on the basis of milk production are similar to the results reported by Sheikh et al., (2011) and encouraging than Divekar et al.(2008) reported by and lower than that observed by Akila et al., (2012). Adoption of feeding of extra ration to advance pregnant animals are similar to the results reported by Chowdhry et al., (2006) but lower than reported by Sharma et al., (1987).

\section{Adoption of breeding management techniques}

Data in Table 3 indicated that out of ten techniques included in adoption of breeding management, keeping watch on oestrus cycle and heat symptoms of animals got the highest mean score and got first rank. The second and third positions were occupied by service/ insemination after 12-16 hours since onset of heat and artificial insemination of animals, respectively. Practicing pregnancy diagnosis between 60-90 days after service, treatment of anoestrus/repeat breeder, considering age and weight of heifers at first breeding, breeding after 60-90 day of calving, keeping record of service, calving and heat detection occupied the rank of $4^{\text {th }}, 5^{\text {th }}, 6^{\text {th }}, 7^{\text {th }}$ and $8^{\text {th }}$, respectively. Adequate exercise to pregnant animal and natural service with bulls of superior breed occupied the rank of $9^{\text {th }}$ and $10^{\text {th }}$, respectively. The high adoption of keeping watch on oestrus cycle and heat symptoms of animals, service/insemination after 12-16 hours since onset of heat, artificial insemination of animals and practicing pregnancy diagnosis between 60-90 days after service by the respondents were due to the fact that the respondents had more awareness about these techniques as they are directly affecting the economy of farmers.

\section{Adoption of health care management techniques}

Adoptions of health care management techniques are presented in Table 4 revealed that out of ten techniques, timely and regularly vaccination got the highest mean score and awarded first rank. The second and third positions were occupied by observing animals daily for signs of sickness and proper cleaning and sanitation of shed, respectively. Deworming of animals, treatment of reproductive disorder, lice and tick eradication, proper treatment of sick animals by veterinarians, proper method of disposing of carcass of dead animals and isolation of sick animals from healthy ones were awarded $4^{\text {th }}, 5^{\text {th }}, 6^{\text {th }}, 7^{\text {th }}, 8^{\text {th }}$, and $9^{\text {th }}$ rank, respectively. While, the last rank was awarded to prompt reporting of outbreak of contagious diseases to local veterinarians.

\section{Adoption of milking management techniques}

Data presented in Table 5 indicated that out of ten techniques included in adoption of milking management, washing pails and hands before milking had obtained the highest mean score which revealed that the respondents had adopted these techniques to the extent of 100 percent, hence this was ranked first. Similarly, Practices of milking politely, gently, quickly and quietly, preparation of animal before milking, regularity in milking time, complete milking followed by stripping, keeping milk record, dry hand milking, full hand milking method and proper drying of animal and sealing of teat canal by infusion of intra-mammary ointment had occupied $2^{\text {nd }}, 3^{\text {rd }}, 4^{\text {th }}, 5^{\text {th }}, 6^{\text {th }}, 7^{\text {th }}$, $8^{\text {th }}$ and $9^{\text {th }}$, respectively. While the last rank was awarded to milking in clean and separate place. 
Table.1 Extent of adoption of improved housing management techniques

\begin{tabular}{|c|l|c|c|c|}
\hline $\begin{array}{c}\text { Sr. } \\
\text { No. }\end{array}$ & \multicolumn{1}{|c|}{ Practices } & $\begin{array}{c}\text { Total } \\
\text { adoption } \\
\text { score }\end{array}$ & $\begin{array}{c}\text { Mean } \\
\text { score }\end{array}$ & $\begin{array}{c}\text { Rank } \\
\text { order }\end{array}$ \\
\hline $\mathbf{1 .}$ & Housing in separate located place & 540 & 1.80 & I \\
\hline $\mathbf{2 .}$ & Proper orientation of animal shed & 436 & 1.45 & II \\
\hline $\mathbf{3 .}$ & Providing proper floor space & 298 & 0.99 & III \\
\hline $\mathbf{4 .}$ & Proper height and ventilation & 282 & 0.94 & IV \\
\hline $\mathbf{5 .}$ & Provision of pucca paved floor in the shed & 274 & 0.91 & V \\
\hline $\mathbf{6 .}$ & $\begin{array}{l}\text { Keeping animals in the shed at night and outside } \\
\text { during day time in winter season vice-a-versa in } \\
\text { summer }\end{array}$ & 254 & 0.85 & VI \\
\hline $\mathbf{7 .}$ & Providing pucca manger & 200 & 0.67 & VII \\
\hline $\mathbf{8 .}$ & Proper drainage and slope of floor & 182 & 0.61 & VIII \\
\hline $\mathbf{9 .}$ & $\begin{array}{l}\text { Providing bedding material on the floor during } \\
\text { winter }\end{array}$ & 084 & 0.28 & IX \\
\hline $\mathbf{1 0 .}$ & Loose housing with seasonal modification & 000 & 0.00 & $\mathrm{X}$ \\
\hline
\end{tabular}

Table.2 Extent of adoption of improved feeding management techniques

\begin{tabular}{|c|l|c|c|c|}
\hline $\begin{array}{c}\text { Sr. } \\
\text { No. }\end{array}$ & \multicolumn{1}{|c|}{ Practices } & $\begin{array}{c}\text { Total } \\
\text { adoption } \\
\text { score }\end{array}$ & Mean score & $\begin{array}{c}\text { Rank } \\
\text { order }\end{array}$ \\
\hline $\mathbf{1 .}$ & Provide clean and fresh drinking water & 594 & 1.98 & I \\
\hline $\mathbf{2 .}$ & $\begin{array}{l}\text { Feeding balance concentrate mixture on the basis } \\
\text { of milk production }\end{array}$ & 430 & 1.43 & II \\
\hline $\mathbf{3 .}$ & $\begin{array}{l}\text { Feeding extra ration to advance pregnant } \\
\text { animals }\end{array}$ & 419 & 1.40 & III \\
\hline $\mathbf{4 .}$ & Cultivation of green fodders & 386 & 1.29 & IV \\
\hline $\mathbf{5 .}$ & Feeding mineral mixture & 358 & 1.19 & V \\
\hline $\mathbf{6 .}$ & Feeding green fodders to animal round the year & 219 & 0.73 & VI \\
\hline $\mathbf{7 .}$ & Chaffing of dry fodders before feeding & 030 & 0.10 & VII \\
\hline $\mathbf{8 .}$ & Feeding of common salt & 008 & 0.03 & VIll \\
\hline $\mathbf{9 .}$ & $\begin{array}{l}\text { Urea treatment for improving the poor quality } \\
\text { paddy straw }\end{array}$ & 000 & 0.00 & IX \\
\hline $\mathbf{1 0 .}$ & $\begin{array}{l}\text { Preservation of surplus green fodder as hay } \\
\text { and silage }\end{array}$ & 000 & 0.00 & IX \\
\hline
\end{tabular}


Table.3 Extent of adoption of improved breeding management techniques

\begin{tabular}{|c|l|c|c|c|}
\hline $\begin{array}{c}\text { Sr. } \\
\text { No. }\end{array}$ & \multicolumn{1}{|c|}{ Practices } & $\begin{array}{c}\text { Total } \\
\text { adoption } \\
\text { score }\end{array}$ & $\begin{array}{c}\text { Mean } \\
\text { score }\end{array}$ & $\begin{array}{c}\text { Rank } \\
\text { score }\end{array}$ \\
\hline $\mathbf{1 .}$ & $\begin{array}{l}\text { Keeping watch on oestrus cycle and heat } \\
\text { symptoms of animals }\end{array}$ & 593 & 1.98 & 1 \\
\hline $\mathbf{2 .}$ & $\begin{array}{l}\text { Service/insemination after 12-16 hours since onset } \\
\text { of heat }\end{array}$ & 575 & 1.92 & II \\
\hline $\mathbf{3 .}$ & Artificial insemination of animals & 538 & 1.79 & III \\
\hline $\mathbf{4 .}$ & $\begin{array}{l}\text { Practicing pregnancy diagnosis between } \\
\text { 60-90 days after service }\end{array}$ & 536 & 1.78 & IV \\
\hline $\mathbf{5 .}$ & Treatment of anoestrus/repeat breeder & 453 & 1.51 & V \\
\hline $\mathbf{6 .}$ & $\begin{array}{l}\text { lonsidering age and weight of heifers at first } \\
\text { breeding }\end{array}$ & 374 & 1.25 & VI \\
\hline 7. & Breeding after 60-90 day of calving & 346 & 1.15 & VII \\
\hline $\mathbf{8 .}$ & $\begin{array}{l}\text { Keeping record of service, calving and } \\
\text { heat detection }\end{array}$ & 243 & 0.81 & VIII \\
\hline 9. & Adequate exercise to pregnant animal & 179 & 0.60 & IX \\
\hline $\mathbf{1 0 .}$ & Natural service with bulls of superior breed & 062 & 0.21 & X \\
\hline
\end{tabular}

Table.4 Extent of adoption of improved health care management techniques

\begin{tabular}{|c|l|c|c|c|}
\hline $\begin{array}{c}\text { Sr. } \\
\text { No. }\end{array}$ & \multicolumn{1}{|c|}{ Practices } & $\begin{array}{c}\text { Total } \\
\text { adoption } \\
\text { score }\end{array}$ & $\begin{array}{c}\text { Mean } \\
\text { score }\end{array}$ & $\begin{array}{c}\text { Rank } \\
\text { order }\end{array}$ \\
\hline $\mathbf{1 .}$ & Timely and regularly vaccination & 580 & 1.93 & I \\
\hline $\mathbf{2 .}$ & Observing animals daily for signs of sickness & 544 & 1.81 & II \\
\hline $\mathbf{3 .}$ & Proper cleaning and sanitation of shed & 441 & 1.47 & III \\
\hline $\mathbf{4 .}$ & Deworming of animals & 410 & 1.37 & $1 \mathrm{~V}$ \\
\hline $\mathbf{5 .}$ & Treatment of reproductive disorder & 326 & 1.09 & V \\
\hline $\mathbf{6 .}$ & Lice and tick eradication & 309 & 1.03 & VI \\
\hline $\mathbf{7 .}$ & Proper treatment of sick animals by veterinarians & 227 & 0.76 & VII \\
\hline $\mathbf{8 .}$ & $\begin{array}{l}\text { Proper method of disposing of carcass of dead } \\
\text { animals }\end{array}$ & 109 & 0.36 & VIII \\
\hline $\mathbf{9 .}$ & Isolation of sick animal from healthy ones & 097 & 0.32 & IX \\
\hline $\mathbf{1 0 .}$ & $\begin{array}{l}\text { Prompt reporting of outbreak of a contagious } \\
\text { diseases to local veterinarians }\end{array}$ & 050 & 0.17 & $\mathrm{X}$ \\
\hline
\end{tabular}


Table.5 Extent of adoption of improved milking management techniques

\begin{tabular}{|c|l|c|c|c|}
\hline $\begin{array}{c}\text { Sr. } \\
\text { No. }\end{array}$ & \multicolumn{1}{|c|}{ Practices } & $\begin{array}{c}\text { Total } \\
\text { adoption } \\
\text { score }\end{array}$ & Mean score & $\begin{array}{c}\text { Rank } \\
\text { order }\end{array}$ \\
\hline 1. & Washing pail and hands before milking & 600 & 2.00 & I \\
\hline 2. & $\begin{array}{l}\text { Practices of milking politely, gently, quickly and } \\
\text { quietly }\end{array}$ & 590 & 1.97 & II \\
\hline 3. & Preparation of animal before milking & 586 & 1.95 & III \\
\hline $\mathbf{4 .}$ & Regularity in Milking time & 581 & 1.94 & IV \\
\hline $\mathbf{5 .}$ & Complete milking followed by stripping & 414 & 1.38 & V \\
\hline $\mathbf{6 .}$ & Keeping milking record & 131 & 0.44 & VI \\
\hline 7. & Dry hand milking & 074 & 0.25 & VII \\
\hline $\mathbf{8 .}$ & Full hand milking method & 056 & 0.19 & VIII \\
\hline 9. & $\begin{array}{l}\text { Proper drying of animal and sealing of teat canal by } \\
\text { infusion of intra-mammary ointment }\end{array}$ & 004 & 0.01 & IX \\
\hline $\mathbf{1 0 .}$ & Milking in Clean and separate place & 000 & 0.00 & $\mathrm{X}$ \\
\hline
\end{tabular}

Table.6 Extent of adoption of improved calf rearing management techniques

\begin{tabular}{|c|l|c|c|c|}
\hline $\begin{array}{c}\text { Sr. } \\
\text { No. }\end{array}$ & \multicolumn{1}{|c|}{ Practices } & $\begin{array}{c}\text { Total } \\
\text { adoption } \\
\text { score }\end{array}$ & $\begin{array}{c}\text { Mean } \\
\text { score }\end{array}$ & $\begin{array}{c}\text { Rank } \\
\text { order }\end{array}$ \\
\hline $\mathbf{1 .}$ & $\begin{array}{l}\text { Attending newly born calf and proper cleaning of } \\
\text { mucous from mouth and nostrils }\end{array}$ & 572 & 1.91 & I \\
\hline $\mathbf{2 .}$ & Early solid feeding & 529 & 1.76 & II \\
\hline $\mathbf{3 .}$ & Trimming of hooves & 473 & 1.58 & III \\
\hline $\mathbf{4 .}$ & Regular Deworming of calf & 414 & 1.38 & IV \\
\hline $\mathbf{5 .}$ & Milk feeding to calf upto three months & 397 & 1.26 & V \\
\hline $\mathbf{6 .}$ & Right time and method of dehorning & 222 & 0.74 & VI \\
\hline $\mathbf{7 .}$ & Feeding of colostrums to newly born calf within & 204 & 0.68 & VII \\
\hline & one hour after birth & 153 & 0.51 & VIII \\
\hline $\mathbf{8 .}$ & Right time and method of castration & 074 & 0.25 & IX \\
\hline 9. & $\begin{array}{l}\text { Providing bedding material on floor in winter } \\
\text { season }\end{array}$ & 031 & 0.10 & $\mathrm{X}$ \\
\hline $\mathbf{1 0 .}$ & Ligating and disinfection of naval cord & &
\end{tabular}

Adoption of calf rearing management techniques

Adoption of calf rearing management presented in Table 6 revealed that out of ten techniques, attending newly born calf and proper cleaning of mucous from mouth and nostrils got the highest mean adoption score and occupied first rank. The second and third positions were occupied by early solid feeding and trimming of hooves, respectively. Regular deworming of calves, milk feeding to calves upto three months of age, right time and method of dehorning, feeding of 
colostrums to newly born calves within one hour after birth, right time and method of castration, Providing bedding material on floor in winter season and legating and disinfection of naval cord were awarded $4^{\text {th }}$, $5^{\text {th }}, 6^{\text {th }}, 7^{\text {th }}, 8^{\text {th }}, 9^{\text {th }}$ and last rank respectively.

It can be concluded that provision of bedding material on the floor during winter, providing pucca manger and proper drainage and slope of floor in animal shed were least adopted by the dairy animal owners. Very few respondents adopted the chaffing of dry fodders, feeding of common salt and feeding of green fodders. Records keeping and other routine farm operations were least adopted technique in breeding and health care management. Very few respondents adopted feeding of colostrums to new born calf within one hour after birth and ligating and disinfection of naval cord.

\section{References}

Akila, N. and Senthilvel, K. 2012. Status of dairy farming in Karur district of Tamil Nadu. Indian Journal of Animal Research. 46(4): 401-403.

Chowdhry, N.R., Patel, J. B. and Bhakat, M. 2006. An overview of feeding, breeding and housing practices of dairy animals under milk co- operative system in Banaskantha district of North Gujarat region. Dairy Planner. 5: 8-10.
Divekar, B. S. and Saiyed, L.H. 2008. Feeding practices followed by professional cattle owners of Anand district. Indian Journal of Field Veterinarians. 3(4):31-34.

Gupta, D. C., Suresh, A. and Mann, J. S.2008. Management practices and productivity status of cattle and buffaloes in Rajasthan. Indian Journal of Animal Sciences. 78(7): 769-774.

Hegde, N. G. 2006. Livestock development for sustainable livelihood of small farmers. $48^{\text {th }}$ National symposium on Energising rural India- A challenge to livestock industry held 26, August, 2006 at Manesar, Haryana. Pp: 50-63.

Kumar, S. and Mishra, B. K. 2011. Existing feeding and housing management practices followed by dairy producers in Tehri Garhwal district of Uttarakhand. Indian Journal of Animal Production Management. 27(3-4): 159-162.

Sharma, R. K. and Sohil, T. S. 1987. A scale for measuring adoption of dairy innovations. Indian journal of Extension Education. 23(1): 68-71.

Sheikh, A. S., Bhati, D. S. and Sheikh, W. 2011. Feeding practices followed by professional Kankrej cow owners of Banaskantha district of North Gujarat. Journal of Progressive Agriculture, 2(1): 67-69.

\section{How to cite this article:}

Geetha, T., P. Tensingh Gnanaraj, U. Lakshmikantan, R. Mathivanan and Manokaran, S. 2020. Field Survey on Extent of Adoption of Improved Dairy Husbandry Techniques in Erode District of Tamil Nadu, India. Int.J.Curr.Microbiol.App.Sci. 9(04): 1881-1887. doi: https://doi.org/10.20546/ijcmas.2020.904.222 